\title{
JEWISH HERITAGE IN THE CREATIVE CITIES OF CENTRAL AND EASTERN EUROPE: TOURISM, TECHNOLOGIES AND PROSTHETIC MEMORY
}

\author{
Žilvinè GAIŽUTYTĖ-FILIPAVIČIENË* \\ Lithuanian Culture Research Institute, Department of Comparative Culture Studies, \\ Saltoniškiu g. 58, LT-08105 Vilnius, Lithuania
}

Received 15 October 2018; accepted 5 December 2019

\begin{abstract}
This paper deals with Jewish mobile multimedia cultural-heritage, root-diaspora tours and apps. The author presents and compares UNESCO Creative Cities Network of Central and Eastern Europe in which Jewish communities were numerous before the World War II - Budapest (Hungary), Kraków (Poland), Prague (Czech Republic), Kaunas (Lithuania). Also, article deals with other cities of Jewish cultural heritage that are not listed in UNESCO Creative Cities Network as Warsaw, Poland and Vilnius, Lithuania, but propose multimedia tours. I will analyse, how aspects of creative city are included and highlighted in multimedia tours and apps. Visiting of memory sites is very relevant aspect of memory culture, related to other creative and cultural industries - tourism, heritage, museums etc. Cityscape and sites of memory of the Holocaust as cultural topography materialize and embody traumas, regrets, and responsibility to remember past. Contemporary technologies as mobile multimedia tours and apps are designed to aid travellers and tourists to find heritage and other touristic objects in a map, it provides general practical information, as well as maps, photos, augmented reality, and Jewish itineraries. Herewith these new technologies are changing very deeply not only travelling habits or photography practices, they fundamentally transform our relation with cultural heritage and memory. Mobile phones became not only devices for communication, but also as digital prosthetic memory.
\end{abstract}

Keywords: cityscape, creative cities Network, heritage tours, Jewish heritage, mobile multimedia tours, prosthetic memory, UNESCO.

\section{Introduction}

Visiting realms of national histories and memories is very relevant aspect of contemporary culture of memory, related to other domains of cultural industries. Since 1960s travelling around places of national history, familial or personal stories and search for identity has become more relevant and today we know different types of tourism: heritage tours, cultural tours, root tours, and diaspora tours. These heritage or roots tours intensified activities of museums and other realms of memory that caused gradually industrialization and

*Corresponding author. E-mail: zilvine@gmail.com 
commercialization of memory. This search of memory and root sometimes is called as pilgrimage tours having in mind wider cultural meaning of this notion. This "boom" of culture of memory in the late 20th century partially can be explained as Jewish-Christian worldview, with deeper tradition of Judaism, and experiences of Jewish diaspora. Efforts to commemorate of World War II (WWII) and the Holocaust activated all domains of memorial culture, in which appeared structures of consciousness and ritual practices.

The goal of this article is to analyse theoretical approaches to cultural and memorial tourism including also the notion of memory sites in contemporary cityscapes. Focusing on the idea of technological prosthetic memory, the object of this research is Jewish mobile multimedia cultural-heritage, root-diaspora tours and apps. My aim is to contribute to the explorations of prosthetic memory presenting and comparing cultural multimedia tours of cities (or country tours) in Central and Eastern Europe in which Jewish communities were numerous before the WWII: Budapest, Kaunas, Kraków, Prague, Warsaw, Vilnius, etc. Visiting of memory sites is very relevant aspect of memory culture, related to other creative and cultural industries tourism, heritage, museums etc. Few of these cities are also members of UNESCO Creative Cities Network (CCN). This project launched in 2004 to promote cooperation among cities that consider cultural industries and creativity as essential drivers in urban development.

The network aims to strengthen the creation, production, distribution and dissemination of cultural activities, goods and services; develop hubs of creativity and innovation and broaden opportunities for creators and professionals in the cultural sector; improve access to and participation in cultural life, in particular for marginalized or vulnerable groups and individuals; fully integrate culture and creativity into sustainable development plans. CCN covers seven creative fields: crafts and folk art, design, film, gastronomy, literature, media arts, and music. Budapest and Kaunas are cities of design, Kraków and Prague are cities of literature. Article will analyse, in which ways aspects of creative city ideas and urban development are included and highlighted in promotion of cultural heritage and tourism, especially in Jewish multimedia tours and apps.

Cityscape with rich cultural heritage and sites of memory of the Holocaust as cultural topography materialize and embody traumas, regrets, and responsibility to remember past. Contemporary technologies as mobile multimedia tours and apps are designed to aid travellers and tourists to find heritage and other touristic objects in a map, it provides general practical information, as well as maps, photos, augmented reality, and Jewish itineraries. It also raises questions, how these new technologies change our travelling habits and photography practices? How mobile phones being digital prosthetic memory transform our relation with cultural heritage and memory?

This paper develops few theses about processes of memory, creativity and visual experience. New mobile technologies being digital prosthetic memory changed our habits of traveling and taking photos as well as transformed our deep relation with cultural heritage and memory. Active tourist, photographer and social networker immediately transforms common sites of memory to personal narratives and visual sharable documentary. Secondly, Jewish memory, cultural and atrocity heritage were industrialized and adapted to touristic needs and creativity is an important aspect of this industrialization. Jewish multimedia tours and apps include and highlight ideas of creative city and urban development. 
Many researchers analysed contemporary transformations of memory due to the technological progress. An idea of memobilia developed by Anna Reading (2009) is very useful in this research. Literature on dark tourism industry of Gregory J. Ashworth (2002) and Andrea Witcomb (2013) contributed to the explorations of collective efforts to memorialize, of atrocity heritage industry and its adaptation touristic needs. Progress in dark tourism and its relation to heritage tourism was analysed by Duncan Light (2017).

Research is made applying Reading's and Ashworth's theoretical approaches on memory and tourism. It employs qualitative method of content analysis for textual and visual information that is presented in multimedia tours and apps for Jewish heritage.

The article consisted of three main parts. First of all, it reveals retrospective and evolution of Jewish pilgrimage, cultural tours and atrocity heritage in 20th century. Then, traces of mass tourism in the places of massacre are analysed using examples of contemporary artistic researches and documentary aesthetics. And finally, there is presented examples of apps and navigation in Jewish heritage in Eastern European creative cities.

\section{Pilgrimage, cultural tours and atrocity heritage}

In the 1st half of 20th century French historian Maurice Halbwachs revealed that religious places - traces of Christian memory in Palestinian landscape - allowed to formulate an idea about collective memory. In 1941 he published an essay about topography of holy land (Halbwachs, 2008) in which were revealed mechanisms of collective memory and evolution of devotion, emphasizing, that intensive creation of topography reflects changing demands of belief. Localisation of Via Dolorosa clearly reveals interconnection and "competition" of different traditions that are seen in cityscape of Palestine and Jerusalem. For example, adjusting to the needs of Western Christian pilgrims, places of Via Dolorosa were marked with memorials and Palestine became places of Christian memory, when Christianity became official religion of Roman Empire. Halbwachs revealed, that official memory depended on theological dogma and Church. Relevance of textual and visual culture in Christianity and its legitimation as religious group discloses common structure of transformation of collective memory and its continuous "reconstructions" (Brian, 2008).

For Jewish tourists, tours and travels with cultural heritage, roots or other aims, have religious (sacred) and secular motives. Initial aim of pilgrimage tour is sacred, religious visiting of sacred places, cultural tours often are secular, but as Noga Collins-Kreiner claims it

"is a culturally constructed polarity that blurs travelers' motives [...] Between the two exists an almost endless range of possible sacred-secular combinations, with a central area that has come to be referred to generally as "religious tourism" (2010, p. 260).

These combinations reflect the multiple and changing motivations of travelers, whose interests and activities may change - consciously or subconsciously - from tourism to pilgrimage and vice versa (Collins-Kreiner, 2010, p. 260). Marketing of cultural tourism "produces" pilgrimage routes and focuses on monuments and museums. On history of Jewish nation focused tours strengthen, construct travellers' Jewish identity. Roots tourism spread among Jewish people after the fall of Communism in Eastern and Central Europe. Emigrants from Lithuania and other post-soviet countries visited their ancestors' native lands. Root tours 
covered territory from Poland, Ukraine to Belarus ad Lithuania, where before the WWII lived large Jewish diasporas.

In recent decades, researchers of tourism and heritage industry apply notion of dark tourism. Malcolm Foley and J. John Lennon analysed American president John F. Kennedy's death and defined dark tourism as visiting of places and participating in events, that are related to death, suffering, violence, which have long lasting impact to collective consciousness (Foley \& Lennon, 1996). Regarding from historical perspective dark tourism is old phenomenon (e.g. Christian pilgrimage or Baroque death culture). In recent years, dark tourism industry is growing also due to the media and remediation of historical events.

As Witcomb notes, visits to terror museums and sites of traumatic heritage increasingly include encounters with the abject - with horror, depravity or terror, it stimulates different human emotions. Memorialisation of Berlin, Germany -

"new placards, monuments and memorials now commemorate a past that Berlin had left unacknowledged. Much of it comes from a desire for redemption, the need to memorialize in order to grieve and the need to demarcate the present from the past while also recognizing the ongoing effects of the past on the present. But it also comes from the recognition that Germany's unique position in the history of twentieth century terror is a commodity that can be traded - it brings visitors" (Witcomb, 2013, pp. $152-153)$.

Cultural heritage tours include the Holocaust sites, Nazi concentration camps, ghettos of Budapest, Kraków, Prague, Warsaw, Vilnius, etc. Today's one of the most visited places is Auschwitz concentration camp in Poland in post-war period was strictly protected. In 1947 according to resolution of Polish parliament here was established museum-memorial. In 1955 exposition was opened. Since 1960s here have been organized national exhibitions, in 1979 memorial is in the list of UNESCO's world heritage. Kraków is also popular destination among Jewish travellers. Here was reconstructed former Jewish Quarter, which became recognizable after famous remediation in Steven Spielberg's movie Schindler's List (1993). Oskar Schindler's tourism includes tour and itinerary with authentic places that are showed in film. Ashworth referring to phenomenon of Kraków-Kazimierz Quarter wrote about dissonant heritage (2002). He revealed, that management of dissonant heritage poses many challenges, because exploration of atrocity heritage requires combination of educational and entertaining purposes. As touristic entertainment atrocity heritage is to a certain degree "de-heritaged" and this situation always cause a conflict between protectors of heritage and history and managers of atrocity heritage (Ashworth, 2002).

Contemporary heritage industry is socioeconomic and political process. In a global competition for tourist flows, cultural tourism industry creating new products and renewing old destinations focuses on Jewish cultural heritage. There are different reasons - attention to other cultures, feeling guilty about the Holocaust, romantic nostalgia of lost past, reconstruction of important part of national memory, also other economic interests of tourism industry. Tourism industry conforms to contemporary demands and tendencies and different heritage types - even dissonant or atrocity heritage - becomes as well sold products. Today's the Holocaust tourism can be attributed as genocide tourism (Beech, 2009), like other world's genocides or Soviet past. 
As Melanie J. Wright notes, "a particular target of this kind of tourism, which may be described as pilgrimage, are young people in their formative years" (2012, p. 137). Since 1988 we know international educational programme and tour March of the Living. The main objective of this programme is visiting of the Holocaust places and former concentration camps. It can be regarded as a part of new heritage tourism or dark tourism. March of the Living take Jewish teenagers and young adults on a tour of the Holocaust sites in Poland and finish by observing the spring memorial days of the Holocaust and founding of the State of Israel in Israel, literally taking participants on a journey from death to life. Birthright Israel offers young people in the diaspora a tour of Israel with the aim of strengthening their Jewish identity through attachment to Israel. Here, pilgrimage in the sense of life-changing journey is instrumentalized to teach particular lessons about Jewishness which are to be experienced as a part of a group (Wright, 2012, p. 137). According to Wright,

"whether participants' experiences match the aims of the organizers of such tours is difficult to measure. Participants may concur, challenge, subvert or otherwise relate to the offerings of an organized travel tour, or have various motivations for participating, such as being young and looking for romance" (2012, p. 137).

\section{Traces of mass tourism in the places of massacre}

This part focuses on ethics, habits and behaviour of selfie generation in places of massacre. New controversial attitude and habits as taking selfies and instantly uploading them in social media ("I'm here") are caused also by new mobile technologies. Shahak Shapira is a German artist and satirist of Israeli descent. He studied in Berlin and created a project Yolocaust (2017). He designed special website and displayed photos, that satirise touristic habits of taking photos in unusual postures, smiling or "duck faces" in a background of concentration camps or other the Holocaust memorial sites (Hartley-Parkinson, 2017). Acronym YOLO in Internet slang means you only live once, so Yolocaust ironically discloses all hipsters and image hunters. Artist has taken people's selfies from Facebook, Instagram, Tinder and Grindr that are taken by young travellers in the Memorial to the Murdered Jews of Europe in Berlin. Shapira changed the background of memorial to documentary images from death camps with bodies of killed people, heap of shoes, clothes, barracks of concentration camps, mass graves. Author evidently demonstrated dramatic dissonance of memorial site and travellers' attitude.

Phenomenon of dark tourism and behaviour of tourists were clearly revealed in the film Austerlitz (2016), directed by Ukrainian artist Sergei Loznitsa. This documentary we can interpret also as visual sociological research. Filmmaker situated stationary cameras in Dachau (near Munich, Germany) and Sachsenhausen (near Berlin) concentration camps that observed moving crowds of visitors. In summer heat wearing shorts and T-shirts with slogans Cool Story, Bro, World Tour, Lucky Day, Fuck'n All Problems, Jurrasic Park, with bottles of cool drinks and snacks, visitors slowly move from one building to other, exploring, listening to guide's telling about tragic events, historical remains, and enthusiastically taking photos: in a background of coffins, crematorium, bath and other macabre remains of camp. Film ends 
with scene of crowds that are taking photos and selfies at the gate of camp with German slogan Arbeit marcht frei (in English: Work Sets You Free). As Loznitsa noted,

"the mundane sights of tourists obscure the history of the camps, and scenes of crowds at ease today are a reminder that similar crowds were massacred there 70 years ago" [...]. The tourists are just looking at things like they are from another world [...], like consumers. It's selling horror in small pieces. It looks like that, when you stay outside and just observe people" (Rapold, 2016).

These examples reveal in which ways contemporary media and cinema influences our understanding of history, memory, sites of massacre. As Magdalena Hodalska has argued, taking self-portraits at horror sites, like concentration camps, ground zero or disaster stricken areas, has become a growing trend on social networking sites. Horror covered in the media becomes an attractive background for the ultimate selfies which are a teenagers' way of celebrating life in places of death. These sometimes humorous self-portraits are ghoulish souvenirs providing emotional detachment, and at the same time a link to a greater media narrative (Hodalska, 2017). The reasons of this behaviour are related also to wish to fix traces of human tragedy and egocentrically to become as a part of bigger historical narrative. As Reading notes, mobile phones and new practices of taking photos creates self-narrative, that changes our experience of history, in which we can see new practices of digital storytelling that makes influence to identity of contemporary generations (2009). Mobile phone became not only device of communication, but also a form of digital prosthetic memory - memobilia:

"Mobile digital phone memories or memobilia are wearable, shareable multimedia data records of events or communications. They are captured on the move, easily digitally archived and rapidly and easily mobilised. They may be saved as a personal note, shared via the mobile-phone handset with a chosen few or circulated to the many by individuals or via websites" (Reading, 2009, p. 81).

Virtual space is flooded by memories of Facebook, Twitter or other users of social networks: according to Facebook 2017 statistics, 1.94 billion users everyday upload 300 million images. $^{1}$

\section{Navigation in Jewish heritage}

In the 1970s memories about the Holocaust tragedy became more intensive and Lufthansa heritage tour started to organize Jewish heritage tours in three countries Germany, Austria, and Czechoslovakia. During these tours travellers were navigated in the cultural heritage of lost European Jewish communities and their realms of memory. As Nils Roemer argued, "the heritage tour thus became a collective quest that aimed to revive the memory of central European Jewish life among contemporary Jews" (2010, p. 194). After the fall of communism in 1990s, cities of Eastern and Central Europe such as Budapest, Kraków, Prague, Warsaw, Vilnius etc. were introduced to itineraries of Jewish travellers.

In the 2 nd decade of 21 st century when mobile technologies and devices are used everywhere, mobile multimedia tours and apps are created for tourists and travellers. These apps

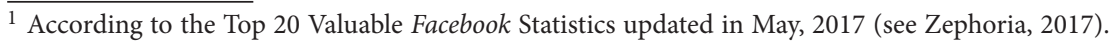


and tours are virtual city guide that helps to find out heritage places and other objects using audio-visual and textual information. These apps have few main functions. Firstly, traveller is provided by navigation with Global Positioning System and Google Street View technology that allows select itinerary and find out an object in a map. Secondly, traveller also is provided by cultural, historical, and practical information in different languages in audio-visual and textual form. Very often tourist here can find out practical information about restaurants, events, currency exchange, etc. Sometimes, these apps also have possibility to create personal visual and textual diary of the tour or have educational function - travellers can test their knowledge about cultural heritage sites etc. There are cities that have multimedia tours.

In the recent years in Poland mobile multimedia heritage tours were created for Kraków-Kazimierz Quarter, Warsaw Jewish heritage and a special guide about Warsaw ghetto. App Kraków-Kazimierz created in 2015 is for visitors of old Krakówian (UNESCO City of Literature) Jewish Quarter. Historians argue that Jews settled in Kraków near the Wawel Hill already in the 11th century. History of Kazimierz began in the middle of 14th century, then Kazimierz as a separate town was founded by king Casimir III the Great in 1335. After the city fire in 1494, which the Jewish community was accused of starting, most of them left Kraków moving to the nearby town of Kazimierz. The Jews lived there probably from the very beginning, but a written confirmation of this fact can be found only in documents from the 15th century. Kazimierz also is related to literature and book printing. From the first half of the 16th century, first printing houses in Poland, where books were printed in Hebrew and Yiddish, also operated in Kazimierz.

After WWII until the 1990s population in Kazimierz was small, later this quarter with small hotels, restaurants of kosher food, bars became popular among locals. For development of this quarter and tourism of Jewish culture and memory has an impact movie Schindler's List directed by Spielberg. This story was filmed in former Krakówian Jewish Quarter and Kraków-Płaszów concentration camp. Since 1990s there have been reconstructed seven synagogues, three museums of Jewish culture, kosher food restaurants and other objects. In 2010 Schindler's Factory museum was opened to visitors as a part of Historical Museum of Kraków. This museum won award as the best European museum in 2010. Jews from all over the world arrive to visit the factory, where Schindler saved more than 1000 Jews.

Industrialization of memory and commodification of cultural heritage, which are evident in Kazimierz Quarter, is evaluated critically by insightful travellers: spirit of this place is disappearing irreversible:
"Indeed the mass of Jewish style cafes shops and restaurants playing Jewish music in the cobblestone streets of Kazimierz oozes yiddishkeit unlike anywhere else outside Jerusalem alas without a Jewish population enabling one local calling area JEWrassic PARK, enjoy it is trendy to be a Jew in Poland today and the locals are desperate to meet actual Jews from abroad [...] They will leave this double experience with a sad feeling of a great loss". ${ }^{2}$

Visit of Kazimierz Quarter often is combined with tour to Auschwitz concentration camp - the most visited place in Poland today (with 2.1 million visitors during 2017). The

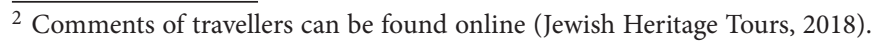


app Kraków-Kazimierz has information in two languages Polish and English, a map without navigation with main streets of this quarter. More information we can get choosing name of street. Then travellers find out description about objects of cultural heritage, their historical and today's images. Also we can find information about restaurants and entertainments. Content of this app and city tour have not any relation with Kraków as design city idea.

Visitors of Warsaw can use two multimedia tours of Jewish heritage and memory. The first one is created in POLIN Museum of the History of Polish Jews (MHPJ) - Warsaw, Varshe (O. H. Media Sp. z o.o., 2016). The second one is app Warsaw Ghetto (Transition Technologies, 2014). In 2014 POLIN MHPJ organised exposition "Warszawa, Varshe" (curator Ewa Małkowska-Bieniek, 2014). This exposition was dedicated to prosperous history of Warsawian Jewish community of pre-war period. Life of this community was documented in visual and textual material. Exposition got a lot intention (March-June, 2014 was visited by more than 35000 visitors) and this fact was a motive to create virtual tour. In 2014 POLIN MHPJ became the first museum in Poland, which can be visited using Google Street View technology. User can virtually view permanent and temporal exposition, additional app immerses to city archaeology from POLIN MHPJ to Grzybowski Square. It is presented with activities of Jewish political, cultural, artistic, and educational institutes, different documents.

Warsaw Ghetto itinerary is composed according to Marzena Swirska-Molenda's recommendations: she works in POLIN MHPJ as a guide. This app is a guide to the most interesting places of Warsaw Ghetto, substitutes traditional maps, and can enlarge experience and knowledge of traveller. It is adapted to individual and collective visiting. User of this app all information can read in three languages: English, German, and Hebrew. App also has detailed map with function of navigation and Google Street View that allows reach cultural object on foot or public transport. Visiting places are marked visually - authors created 3D images of buildings or other objects with textual and visual information.

Budapest as capital of Hungary has also multimedia tour Judapest (Konstruktor Ktf, 2016). Before the WWII Judapest was Jewish Quarter (in present-day 7th Budapest Quarter), but at the turn of 19th and 20th centuries this name had antisemitic connotation. Budapest is listed in UNESCO CCN as city of design. Architectural and design aspects are highlighted in the app: Hungariant Jewish Museum and Archives building, Gyertyánffy House, Gozsdu Court, Stadt Wien House and others. There are situated three synagogues, kosher food restaurants, every year Jewish festivals are taking place. App Judapest has interactive map with navigation, where visitor can find out objects and visiting places with description, photos of buildings interior and exterior, also audio-narrative. Visiting places are classified as baths, cultural centres, educational institutes, historical buildings, Keren Or center/Chabad, museums, public spaces (Jewish Quarter), religious building, restaurants, retail, and statues. Traveller can examine his or her knowledge about Jewish culture and answer to questions in app.

We can find out apps that cover bigger regions or not only one Shtetl. For Jewish heritage in Czech Republic is created apps Jewish Bohemia and Jewish Moravia (Czech Tourism Head Office, 2016). It is dedicated for travels in historical Czech regions - Bohemia in Western part and Moravia in Eastern part. These regions were annexed by Nazi Germany in 1938. Apps has not only region map with objects and navigation. Also here we can find out recommendation with thematic tours according to visitor interests: Boskovice as one of the old 
Jewish settlements, Karlovy Vary as city of Ludwig Moser, founder of a glass-making tradition, Mikulov as place of Judah Loew ben Bezalel, Pilsen as city of one of the world's largest synagogues and Stephen Samuel Wise, Třebíč as very urban heritage, Polná and Terezín as places related to antisemitism and the Holocaust.

Prague as member of UNESCO CCN has long and rich multicultural tradition of literature, which is also inseparable from Jewish community. Jewish literary tradition included into city tours proposed by Jewish Bohemia and Jewish Moravia. For sightseeing of Jewish Prague there are suggested five itineraries - Loew and the legend of Golem, Jewish orthodox, Mordecai Maisel, story of Torahs saved during the war, and Franz Kafka - famous Jewish writer. Kafka tour starts at the native writer's house, then goes to Jewish Town Hall and Old New Synagogue, Statue of Kafka, Kafka's sister's home, different houses, where Kafka lived in different periods of his life, Café Louvre, where Kafka and Max Brod spend long hours discussing literature and Zionism, Kafka Museum and finally his tomb in the New Jewish Cemetery.

Travellers also can find practical information how to reach city, quarter, synagogue, museum or memorial. Authors of this app are chosen the most visited places and objects. Travellers have possibility to mark places in the map and to make individual route. Calendar of events helps to plan a visit, according to Jewish memorial days, cultural events etc. Augmented reality allows look at these cities in different way. For traveller is very practical to have all information about heritage objects in smart phone.

Vilnius is not listed in UNESCO CCN, but for Lithuanian Jews (Litvaks) and connoisseurs of Jewish history Lithuania and in particular Vilnius are place of spiritual centre, city of yeshivas and Jewish religious studies. Jewish root, cultural or religious heritage travellers are interested in objects that are situated in Jewish quarters, shtetls - wooden or synagogues in brick, especially Choral Synagogue, Tolerance Centre of the Vilna Gaon State Jewish Museum. This visit is a part of educational programme that presents life of Jewish community before the WWII and the Holocaust.

In 2016 historians of Center for Studies of the Culture and History of East European Jews in Vilnius University created an app Discover Jewish Lithuania that allows know Jewish culture, history, and heritage using mobile technologies. This is an interactive app with augmented reality, dedicated to cities and villages as Degsnès, Joniškis, Kèdainiai, Ukmergè, Valkininkai, Vilnius, and Žagarè. Information in this app is presented in five languages: Lithuanian, English, Hebrew, Polish, and Russian. It has a map with navigation. When traveller finds an object in a map, he can compare historical image and contemporary photo, read or listen information in one of five languages. There we can find information not only about buildings or streets, also about famous people, who lived many years before. Information focuses on Jewish cultural heritage - economic, religious, artistic, scientific, literature heritage and personalities. There are also noted few sites of the Holocaust: Vilnius Jewish Quarter and Vilna Ghetto, where during the WWII lived about 40000 Jews, Paneriai as massacre site, uprising in Vilna Ghetto. Itinerary includes religious and cultural sites of Jewish memory: Jascha Heifetz's music school, historical Sholom Aleichem ORT High School building, Tarbut Gymnasium (today's Community of Lithuanian Jews), former Yiddish Theatre, Rabbis' 
Council, site of former Great Synagogue of Vilna, that was destroyed by Soviets in 1955, Monument to the Vilna Gaon monument and his house.

Kaunas is listed in UNESCO CCN as city of design which has rich artistic heritage from the interwar years and active contemporary artistic life. More than 20 Jewish students studied in Kaunas Art School before the WWII between them was famous painter Arbit Blatas. Kaunas Oldtown also has streets and places, related to Jewish heritage: Abraham Mapu and L. L. Zamenhoff streets, where before the WWII was established Jewish Real-Gymnasium and Schwabe Gymnasium. Visitor can go to the quarter, where in the war period was situated ghetto, the Holocaust sites - Seventh and Ninth Forts, where Jews from different European (Lithuanian, Germany, France) countries were killed. An equivalent of previously analysed apps in this case could be tour Memory Sites (project manager Daiva Citvariene and team, 2015). Tour of Alternative Guide: The Lost Artistic Kaunas tells about history of synagogue, which in the Soviet period served as workshop of a talented painter Rimvidas Jankauskas, where he created his largest canvases and painted visions of synagogue. This part corresponds an idea of Kaunas as city of design.

\section{Conclusions}

Regarding ideas revealed in this article, it is possible to make more general conclusions about processes of memory and visual experience. New technologies change habits of traveling and taking photos as well as transform our understanding of history and past, our deep relation with cultural heritage and memory. Mobile phone in this process becomes not only mean of communication, also as a form of prosthetic spectacle memory. New stages of global capitalism development integrate Jewish memory that became an object of dark tourism industry and atrocity heritage: touristic itineraries often take a form of thematic park with exploitation of historical tragedy and heritage of the Holocaust. Dark tourism itineraries with atrocity heritage acquire their popularity instead of reflective spaces. Active tourist, photographer and social networker, who transforms common sites of memory to personal narratives and visual sharable documentary. Profound cultural reflection and self-consciousness remain in the cultural margins.

\section{References}

Ashworth, G. J. (2002). Holocaust tourism and Jewish culture: The Lessons of Kraków-Kazimierz, International Research in Geographical and Environmental Education, 11(4), 363-367. https://doi.org/10.1080/10382040208667504

Beech, J. (2009). Genocide tourism. In R. Sharpley \& Ph. R. Stone (Eds.), The darker side of travel: the theory and practice of dark tourism (pp. 207-223). Series: Aspects of Tourism. Ch. Cooper, C. M. Hall, \& D. J. Timothy (Series Eds.). Bristol: Channel View Publications. https://doi.org/10.21832/9781845411169-012

Brian, É. (2008). Portée du lexique halbwachsien de la mémoire, in Halbwachs, M. La topographie légendaire des Évangiles en Terre sainte (pp. 113-146). M. Jaisson, D. Hervieu-Léger, J.-P. Cléro, S. Gensburger, \& É. Brian (Éd.). Paris: Presses universitaires de France.

Collins-Kreiner, N. (2010). Current Jewish pilgrimage tourism: modes and models of development. Preliminary Communication, 58(3), 259-270. 
Foley, M., \& Lennon, J. J. (1996). JFK and dark tourism: a fascination with assassination, Journal of International Heritage Studies, 2(4), 198-211. https://doi.org/10.1080/13527259608722175

Halbwachs, M. (2008). La topographie légendaire des évangiles en Terre sainte. Paris: Presses universitaires de France.

Hartley-Parkinson, R. (2017). Powerful images that show why Holocaust memorial selfies are disrespectful. Metro. Retrieved from https://metro.co.uk/2017/01/19/powerful-images-that-show-why-holocaust-selfies-are-so-disrespectful-6391091/

Hodalska, M. (2017). Selfies at horror sites: dark tourism, Ghoulish souvenirs and digital narcissism. Zeszyty Prasoznawcze, 60(2), 405-423. https://doi.org/10.4467/22996362PZ.17.026.7306

Jewish Heritage Tours. (2018). Welcome to JHTee - Jewish heritage tours of Eastern \& central Europe and now worldwide tours. Retrieved from http://www.jewishheritagetours.co.uk/private.html

Light, D. (2017). Progress in dark tourism and Thanatourism research: an uneasy relationship with heritage tourism. Tourism Management, 61, 275-301. https://doi.org/10.1016/j.tourman.2017.01.011

Rapold, N. (2016). Sergei Loznitsa's movie "Austerlitz" observes tourists in concentration camps. The New York Times. Retrieved from https://www.nytimes.com/2016/08/31/arts/international/sergei-loznitsa-movie-austerlitz-tourists-concentration-camps.html?_r=0

Reading, A. (2009). Memobilia: the mobile phone and the emergence of wearable memories. In J. Garde-Hansen, A. Hoskins, \& A. Reading (Eds.), Save as... digital memories (pp. 81-95). Basingstoke: Palgrave Macmillan. https://doi.org/10.1057/9780230239418_5

Roemer, N. (2010). German city, Jewish memory: the story of worms. Series: The Tauber Institute Series for the Study of European Jewry. J. Reinharz (General Ed.). Waltham, MA: Brandeis University Press.

Shapira, Sh. (2017). Yolocaust. Retrieved from https://yolocaust.de/

Witcomb, A. (2013). Using immersive and interactive approaches to interpreting traumatic experiences for tourists: potentials and limitations. In R. Staiff, R. Bushell, \& S. Watson (Eds.), Heritage and tourism: place, encounter, engagement (pp. 152-170). New York: Routledge.

Wright, M. J. (2012). Studying Judaism: the critical issues. Series: Studying World Religions. London, New York: Continuum International Publishing Group.

Zephoria. (2017). The Top 20 valuable Facebook statistics - updated May 2017. Retrieved from https:// zephoria.com/top-15-valuable-facebook-statistics/

\title{
ŽYDŲ PAVELDAS KŪRYBINIUOSE VIDURIO IR RYTŲ EUROPOS MIESTUOSE: TURIZMAS, TECHNOLOGIJOS IR PROTEZINE ATMINTIS
}

\section{Žilvinė GAIŽUTYTĖ-FILIPAVIČIENĖ}

\begin{abstract}
Santrauka
Straipsnyje tyrinejjamas žydų kultūrinis paveldas mobiliosiose technologijose, diasporos ir šaknų paieškos kelionès bei joms skirtos programèlès. Analizuojami ir lyginami Vidurio ir Rytų Europos miestai, kuriuose prieš Antrąji pasaulinị karą gyveno didelès žydų bendruomenès: Budapeštas (Vengrija), Krokuva (Lenkija), Praha (Čekija), Kaunas (Lietuva). Straipsnyje tyrinejami ir kitų žydų kultūros paveldo miestai Varšuva (Lenkija) bei Vilnius (Lietuva), kurie turi keliautojams skirtus multimedijų turus. Atminties vietų lankymas yra labai svarbus atminties kultūros aspektas, kuris kartu susijęs su kitomis kūrybinèmis ir kultūrinèmis industrijomis -
\end{abstract}


turizmu, paveldu, muziejais ir kt. Miestovaizdis ir Holokausto atminties vietos kaip kultūrinè topografija materializuoja ir įkūnija traumas, nuoskaudas ir atsakomybę atsiminti praeitị. Šiuolaikinès technologijos kaip mobilūs multimedijų turai ir programèlès yra sukurti taip, kad padètų keliautojams ir turistams rasti paveldo bei kitus turistinius objektus žemėlapyje, suteikia bendrą praktinę informaciją, pateikia žemèlapius, nuotraukas, taiko papildytąją realybę ir siūlo maršrutus, pritaikytus žydų keliautojui, norinčiam susipažinti su kultūra. Būdamos naudingos, kartu šios technologijos keičia ne tik keliavimo ipročius ar fotografavimo praktikas, bet ir mūsų gelminị santykị su kultūros paveldu bei atmintimi. Mobilieji telefonai tampa ne tik komunikacijos priemone, bet ir skaitmenine protezinès atminties forma.

Reikšminiai žodžiai: miestovaizdis, Kūrybinių miestų tinklas, paveldo kelionès, žydų paveldas, mobilieji multimedijų turai, protezinè atmintis, UNESCO. 